\title{
PENGARUH PENGGUNAAN MEDIA PEMBELAJARAN DAN KREATIVITAS TERHADAP KEMAMPUAN MENULIS HURUF ANAK PAUD
}

\author{
Flora Marantika Ginting 1 , R. Mursid ${ }^{2}$, Mukhtar $^{3}$ \\ ${ }^{1}$ BP-PAUD dan Dikmas Sumatera Utara, ${ }^{2,3}$ Pascasarjana Universitas Negeri Medan \\ floraginting610@yahoo.com ${ }^{1}$,mursid.tp@gmail.com ${ }^{2}$
}

\begin{abstract}
Abstrak: Penelitian ini bertujuan untuk mengetahui: pengaruh media pembelajaran video dan kartu huruf terhadap kemampuan menulis huruf anak usia dini di PAUD Kenanga Raya Medan; pengaruh kreativitas tinggi dan kreativitas rendah terhadap kemampuan menulis huruf anak usia dini di PAUD Kenanga Raya Medan; dan pengaruh interaksi antara media pembelajaran dan kreativitas terhadap kemampuan menulis huruf anak usia dini di PAUD Kenanga Raya Medan. Penelitian ini bersifat eksperimen semu (quasi experiment). Teknik pengambilan sampel dengan menggunakan cluster random sampling, yang terdiri dari dua kelas (kelas A dengan jumlah 20 anak sebagai kelas eksperimen dan kelas $B$ dengan jumlah 20 anak sebagai kelas kontrol) dengan jumlah sampel seluruhnya 40 orang anak yang ditentukan secara acak. Instrumen penelitian menggunakan tes kemampuan menulis dan tes kreativitas. Rentang skor tes kemampuan menulis dari 0-100, sedangkan tes kreativitas dari 0-30. Metode penelitian dengan menggunakan kuasi eksperimen dengan desain faktorial $2 \times 2$. Berdasarkan hasil penelitian diperoleh: Kemampuan menulis huruf anak yang mengikuti pembelajaran dengan menggunakan media pembelajaran video lebih tinggi daripada anak yang mengikuti pembelajaran dengan menggunakan media pembelajaran kartu huruf dimana harga $F_{\text {hitung }}=378.14, F_{\text {tabel }}=4.12$ pada taraf signifikansi alpha $=0,05$; Kemampuan menulis huruf anak yang memiliki kreativitas tinggi lebih tinggi daripada anak yang memiliki kreativitas rendah berdasarkan media pembelajaran, harga $F_{\text {hitung }}=44.5, \quad F_{\text {tabel }}=4.12$ pada taraf signifikansi alpha $=0,05$ dan Terdapat pengaruh interaksi antara belajar dengan menggunakan media pembelajaran dan kreativitas terhadap Kemampuan menulis huruf dengan $F_{\text {hitung }}=90.4, F_{\text {tabel }}=4.12$ pada taraf signifikansi alpha $=0,05$. Hasil penelitian yang diperoleh diharapkan memberikan informasi bagi guru dan sekolah untuk menggunakan media pembelajaran video dalam meningkatkan kemampuan menulis huruf anak PAUD. Selain itu perlu ditingkatkan kreativitas anak dalam pembelajaran di kelas.
\end{abstract}

Kata Kunci : media pembelajaran, kreativitas, kemampuan menulis huruf

Abstract :This research aims to know: the influence of the media learning of video and letters card against the ability of writing letters in the Kenanga Raya Early Childhood Education of Medan; the influence of high creativity and low creativity against the ability of writing letters in the Kenanga Raya Early Childhood Education of Medan; and the influence of the interaction between the media learning and creativity against the ability of the writing letters in the Kenanga Raya Early Childhood Education of Medan. This was a quasi experiment. while the sampling technique using cluster random sampling that consists of two classes (A class with 20 children as an experiment group and B class with 20 children as a control group) with 40 early young children in the Kenanga Raya Early Childhood Education of Medan, which is determined randomly. The research instruments were writing letters ability test, and creativity test. Speaking ability score between 0-100, whilw self concept score between 0-30. Technique of analyzing data used Anava of two direction at $\alpha$ 0.05. The research result shows that: the ability to write the letter that follows the child's learning by using learning media video is higher than the children who follow learning by using learning media card letter where the $F_{\text {count }}=378.14, F_{\text {tables }}=4.12$ on significance level alpha $=0.05$; the ability to write letters that children who have a high creativity higher than children who have low creativity based on learning media, where the $F_{\text {count }}$ $=44.5, F_{\text {tables }}=4.12$ on significance level alpha $=0.05$ and there is an interaction between learning by using learning media and creativity against the ability to write letters where $F_{\text {count }}=90.4, F_{\text {tables }}=4.12$ on significance level alpha $=0.05$. The research finding was expected to give information for teachers and the school to use alphabet flour instructional media to improve the kindergarten pupils' ability of writing letters. Besides it is necessary to improve the pupils' creativity of learning in the classroom.

Keywords : learning media, creativity, to letter writing skills

\section{PENDAHULUAN}

Menurut undang-undang Nomor 20 Tahun 2003 tentang Sistem Pendidikan Nasional menyatakan bahwa "Pendidikan Anak Usia Dini adalah suatu upaya pembinaan yang ditujukan kepada anak sejak lahir sampai dengan usia enam tahun yang dilakukan melalui pemberian 
rangsangan pendidikan untuk membantu pertumbuhan dan perkembangan jasmani dan rohani agar anak memiliki kesiapan dalam memasuki pendidikan lebih lanjut". Menurut Jamaris (2006:8) pada usia 5 atau 6 tahun, koordinasi gerakan motorik halus berkembang dengan pesat. Pada masa ini, anak telah mampu mengkoordinasikan gerakanmotorik, seperti mengkoordinasikan gerakan mata dengan gerakan tangan, lengan, dan tubuh secara bersamaan, antara lain ataudapat dilihat pada waktu anak menulisatau menggambar.

Mengajarkan menulis di TK dapat dilaksanakan dalam batas-batas aturan pengembangan prasekolah serta pada prinsip dasar hakiki dari TK sebagai sebuah taman bermain, sosialisasi, dan pengembangan berbagai pengembangan pra-akademik yang lebih substansi pada bidang pengembangan kemampuan dasar, yang meliputi kemampuan membaca atau berbahasa maupun kemampuan menulis, kognitif, fisik-motorik, dan seni. Dengan serangkaian tindakan itu diharapkan dapat mengubah suasana pembelajaran kearah pembelajaran yang lebih memungkinkan anak didik terlibat secara aktif dan menyenagkan.Anak yang masih rendah kemampuan menulisnya diantaranya ada beberapa anak belum dapat menulis huruf dengan baik, selain itu sebagian anak belum mampu membedakan huruf kapital dan huruf kecil pada saat dia meniru menulis huruf. Hal itu dikarenakan atau dipengaruhi oleh aspek perkembangan lain terutama fisik dan intelektual anak. Rendahnya kemampuan menulis anak disebabkan kondisi pembelajaran yang tidak kondusif.Kondisi tersebut karena guru menerapkan pembelajaran yang monoton dan tidak relevan dengan kondisi anak.Selain itu guru kurang kreatif dalam menyampaikan materi pembelajaran yang berfungsi memediasi timbulnya karakter anak didik menjadi aktif, kreatif, dan inovatif, sehingga anak belajar secara efektif, dan merasa senang.Hal ini menyebabkan kemampuan menulis anak belum optimal.

Penggunaan media merupakan salah satu bantuan yang memiliki peranan yang penting dalam proses pembelajaran anak usia dini, karena media memiliki fungsi sebagai alat bantu untuk memperjelas informasi yang disampaikan oleh pengirim pesan kepada si penerima pesan, yang dalam hal ini guru adalah pengirim pesan dan anak usia dini sebagai penerima pesan. Penggunaan berbagai media membutuhkan pengetahuan dan pemahaman guru maupun orangtua tentang media pembelajaran anak usia dini.

Hasil pengamatan penulis dari beberapa PAUD, diperoleh kesimpulan bahwa masih banyak anak yang akan memasuki tingkat Sekolah Dasar belum memiliki keterampilan menulissecara efektif (mudah ditulis dan mudah diingat)setelah diberikan contoh dan latihan. Melalui media ini diharapkan mampu memberikan motivasi kepada anak agar tidak merasa takut, dan merasa sulit sebelum mencoba untuk menulis kembali tersebut. Kreativitas sebagai kemampuan umum untuk menciptakan sesuatu yang baru, gagasan-gagasan baru yang dapat diterapkan dalam pemecahan masalah dan untuk melihat hubungan-hubungan baru antara unsur-unsur yang telah ada.

Dibidang ilmu pengetahuan, kemampuan pengamatan dan perbandingan, menganalisa dan menyimpulkan lebih menentukan. Keduaduanya menuntut pemusatan perhatian, kemampuan, kerja keras dan ketekunan; keduaduanya bertolak dari intelektualisme dan emosi, serta merupakan cara pengenalan realitas alam dan kehidupan yang sama. Tinggi rendahnya kreativitas anak akan mempengaruhi keberhasilan pengembangan kemampuan anak dan untuk mengetahui kreativitas dalam diri anak dapat dilihat dalam penggunaan media pembelajaran yang dilaksanakan dalam program pendidikan anak.

Menurut Kasanah \& Tuminto (2007:423) kemampuan adalah kesanggupan, kecakapan atau kekuatan. Kunandar (2007:51) mengartikan kemampuan adalah merupakan perilaku yang rasional untuk mencapai tujuan yang dipersyaratkan sesuai dengan kondisi yang diharapkan.Kemampuan merupakan salah satu hal yang harus dimiliki dalam jenjang apapun karena kemampuan memiliki kepentingan tersendiri dan sangat penting untuk dimiliki oleh seseorang. Sifat intelegen harus ditunjukkan sebagai kemahiran, ketepatan dan keberhasilan bertindak, sedangkan sifat tanggung jawab harus ditunjukkan sebagai kebenaran tindakan baik dipandang dari sudut ilmu pengetahuan, teknologi maupun etika (Majid, 2006:5).

Menurut Hurlock (dalam Yusuf, 2000:104) bahwa "keterampilan kemampuan motorik halus atau keterampilan manipulasi meliputi menulis, menggambar, memotong, melempar dan menangkap bola serta memainkan alat-alat permainan.”. Sujiono (2010:13) mengungkapkan bahwa: "kemampuan motorik 
halus adalah keterampilan yang gerakannya hanya melibatkan bagian-bagian tubuh tertentu saja dan dilakukan oleh otot-otot kecil, seperti keterampilan menggunakan jari jemari tangan dan gerakan pergelangan tangan yang tepat". menurut Moeslichatoen (2004:5) motorik halus merupakan kegiatan yang menggunakan otototot halus untuk melakukan pekerjaan menggambar, melipat, menggunting, membentuk dan sebagainya. Menurut pengertian di atas, motorik halus adalah kegiatan yang memanfaatkan otot-otot pada jari tangan.Keterampilan ini menggunakan otot-otot halus yang membutuhkan kecermatan seseorang terutama untuk kegiatan menulis. Pendapat di atas mengungkapkan bahwa kemampuan motorik halus memerlukan kecermatan antara mata dan tangan, dan perlu dilakukan secara berulang-ulang. Benyamin dalam Suyadi (2010:73) menyatakan bahwa tentang penguasaan psikomotorik ditunjukkan oleh gerakan yang kaku sampai pada gerakan yang lancer dan luwes. Berikut adalah stimulus yang dapat diberikan kepada anak:

1) Imitation (Peniruan) adalah keterampilan untuk menentukan suatu gerakan yang telah dilatih sebelumnya. Latihan ini bisa dilakukan dengan cara mendengarkan atau memperlihatkan.

2) Manipulation (Penggunaan Konsep) adalah kemampuan untuk menggunakan konsep dalam melakukan kegiatan. Pada tahap ini perkembangan anak selalu mengikuti arahan, penampakan gerakan, dan menetapkan suatuketerampilan gerak tertentu berdasarkan latihan. Stimulasi yang diberikan pada tahap ini adalah dengan melatih keterampilan tertentu pada anak, seperti menggunakan sendok makan, gunting.

3) Articulation (Perangkaian) adalah kemampuan untuk melakukan serangkaian gerakan secara kombinatif dan berkesinambungan. Kemampuan ini membutuhkan koordinasi antar organ tubuh, saraf, dan mata secara cermat. Stimulasi yang dapat diberikan pada tahap ini adalah menggambar, mengetik, menulis, dan lain sebagainya.

Menurut Mulyati, dkk (2011:13) menulis adalah keterampilan produktif dengan menggunakan tulisan. Menulis dapat dikatakan suatu keterampilan berbahasa yang paling rumit diantara jenis-jenis keterampilan berbahasa lainnya.

Ehri \& McCormick (1998) dalam Carol
Seefeldt (2008: 330) mengatakan bahwa belajar abjad adalah komponen hakiki dari perkembangan baca tulis.Meskipun beberapa anak bisa membaca beberapa kata dan mengenal huruf cetak lingkungan sebelum mereka mengetahui abjad, anak-anak perlu mengetahui abjad untuk akhirnya menjadi pembaca dan penulis yang mandiri dan lancar.

Berdasarkan uraian diatas dapat disimpulkan bahwa yang dimaksud dengan keterampilan menulishuruf adalah kemampuan anak dalam mengkoordinasikan tangan untuk melakukan gerakan secara otomatis, tepat dan akurat dalam menulis huruf "a" sampai " $z$ " secara efektif (mudah ditulis dan mudah diingat dengan bentuk yang telah ditentukan setelah diberikan contoh dan latihan.

Menurut Brewer dalam Nurbiana Dhieni, dkk (2011:3.10-3.11), ada 4 tahapan dalam kemampuan menulis sebagai berikut:

1) Scribble Stage, yaitu tahap mencoret atau membuat goresan. Pada tahap ini anak mulai membuat tanda-tanda dengan menggunakan alat tulis. Pada tahap ini mereka mulai belajar tentang bahasa tulis dan cara mengerjakan tulisan tersebut.

2) Linear Repetitive Stage, yaitu tahap pengulangan linear. Pada tahap ini anak menelusuri bentuk tulisan yang horizontal.

3) Random Letter Stage, yaitu tahap menulis random. Pada tahap ini anak belajar tentang berbagai bentuk yang merupakan suatu tulisan dan mengulang berbagai kata ataupun kalimat.

4) Letter Name Writing or Phonetic Writing, yaitu tahap menulis nama. Pada tahap ini anak mulai menyusun dan menghubungkan antara tulisan dan bunyinya. Anak mulai menulis nama dan bunyi secara bersamaan.

Berdasarkan uraian di atas, dapat disimpulkan bahwa setiap kemampuan menulis yang telah dimiliki oleh anak akan mengalami perkembangan sesuai dengan tahapan perkembangan. Keterampilan menulis pada anak mulai dikembangkan pada saat anak sudah mempelajari berbagai bentuk yang dapat diterima sebagai tulisan dimana anak telah dapat menulis dan menggambar berbagai bentuk, huruf dan angka, melalui latihan secara berkesinambungan.

Menurut Hasnida (2015: 68) media audio visual merupakan kombinasi dari media audio dan media visual atau biasa disebut media pandang dengar.Dengan menggunakan media audio visual, maka penyajian isi tema 
pembelajaran kepada anak akan semakin lengkap dan optimal. Sedangkan menurut Djamarah (2006:124:125) media audio visual adalah media yang mempunyai unsur suara dan unsur gambar. Jenis media ini mempunyai kemampuan yang lebih baik. Media ini dibagi lagi ke dalam:

1) Audio visual Diam, yaitu media yang menampilkan suara dan gambar diam seperti film bingkai suara (sound slides), film rangkai suara, dan cetak suara.

2) Audio visual Gerak, yaitu media yang dapat menampilkan unsur suara dan gambar yang bergerak seperti film suara dan videocassette.

Menurut Sadiman (2007:74) mengatakan bahwa Video sebagai media audio visual yang menampilkan gerak, semakin lama semakin popular dalam masyarakat kita. Sedangkan menurut Arsyad (2014:50) menyatakan film atau gambar hidup merupakan gambar-gambar dalam frame dimana frame demi frame diproyeksikan melalui lensa proyektor secara mekanis sehingga pada layar terlihat gambar itu hidup.

Sementara menurut Smaldino (2011:7) mengatakan bahwa video merupakan media yang menampilkan gerakan, termasuk DVD, rekaman video, animasi komputer, dan sebagainya.

Kelebihan dan keterbatasan video menurut Sadiman (2003:74-75) adalah sebagai berikut :

1) dapat menarik perhatian untuk periodeperiode yang singkat dari rangsangan luar lainnya

2) dengan alat perekam video sejumlah besar penonton dapat memperoleh informasi dari ahli-ahli/spesialis

3) demonstrasi yang sulit bisa dipersiapkan dan direkam sebelumya sehingga pada waktu mengajar guru memusatkan perhatian pada penyajiannya

4) menghemat waktu dan rekaman dapat dapat diputar berulang-ulang

5) kamera TV bisa mengamati lebih dekat objek yang lagi bergerak atau objek yang lagi bergerak atau objek yang berbahaya seperti harimau;

6) keras lemah suara yang ada bisa diatur dan disesuaikan bila akan disisipi komentar yang akan di dengar

7) gambar proyeksi biasa di-"beku"-kan untuk diamati dengan seksama. Guru bisa mengatur dimana dia akan menghentikan gerakan gambar tersebut; Kontrol sepenuhnya di tangan guru; dan

8) ruangan tak perlu di gelapkan waktu menyajikannya.

Hal-hal yang negatif yang perlu diperhatikan sehubungan dengan penggunaan alat perekam pita video dalam proses belajar-mengajar adalah:

1) Perhatian penonton sulit dikuasai, partisipasi mereka jarang dipraktekkan

2) Sifat komunikasinya yang bersifat satu arah haruslah diimbangi dengan pencarian bentuk umpan balik yang lain

3) kurang mampu menampilkan detail dari objek yang disajikan secara sempurna 4) memerlukan peralatan yang mahal dan kompleks.

Sedangkan keuntungan Film dan video menurut Arsyad (2014:50-51) adalah sebagai berikut :

1) Film dan Video dapat melengkapi pengalaman-pengalaman dasar dari siswa ketika mereka membaca, berdiskusi, praktik, dan lain-lain. Film merupakan pengganti alam sekitar dan bahkan dapat menunjukkan objek yang secara normal tidak dapat dilihat, seperti cara kerja jantung ketika berdenyut.

2) Film dan Video dapat menggambarkan suatu proses secara tepat yang dapat disaksikan secara berulang-ulang jika dipandang perlu. Misalnya, langkah-langkah dan cara yang benar dalam berwudhu.

3) Disamping mendorong dan meningkatkan motivasi, film dan video menanamkan sikap dan segi-segi afektif lainnya. Misalnya, film kesehatan yang menyajikan proses berjangkitnya penyakit diare atau eltor dapat membuat siswa sadar terhadap pentingnya kebersihan makanan dan lingkungan.

4) Film dan video yang mengandung nilai-nilai positif dapat mengundang pemikiran dan pembahasan dalam kelompok siswa. Bahkan, film dan video, seperti slogan yang sering didengar, dapat membawa dunia ke dalam kelas.

5) Film dan video dapat menyajikan peristiwa yang berbahaya bila dilihat secara langsung seperti lahar gunung berapi atau perilaku binatang buas.

6) Film dan video dapat ditunjukkan kepada kelompok besar atau kelompok kecil, kelompok yang heterogen, maupun perorangan.

7) Dengan kemampuan dan teknik pengambilan gambar, frame demi frame, film yang dalam kecepatan normal memakan waktu satu minggu dapat ditampilkan satu atau dua 
menit. Misalnya, bagaimana kejadian mekarnya kembang mulai dari lahirnya kuncup bunga hingga kuncup itu mekar.

Video juga bisa dimanfaatkan untuk hampir semua topik, tipe pembelajar, dan setiap ranah: kognitif, afektif, psikomotorik, dan interpersonal. Pada ranah kognitif, pembelajar bisa mengobservasi rekreasi dramatis dari kejadian sejarah masa lalu dan rekaman aktual dari peristiwa terkini, karena unsur warna, suara dan gerak di sini mampu membuat karakter berasa lebih hidup.

Lebih dari itu, manfaat dan karakteristik lain dari media video atau film dalam meningkatkan efektifitas dan efesiensi proses pembelajaran, di antaranya adalah (Munadi, 2010:127; Smaldino, 2011: 311-312):

1) Mengatasi jarak dan waktu

2) Mampu menggambarkan peristiwa-peristiwa masa lalu secara realistis dalam waktu yang singkat

3) Dapat membawa siswa berpetualang dari negara satu ke negara lainnya, dan darimasa yang satu ke masa yang lain.

4) Dapat diulang-ulang bila perlu untuk menambah kejelasan

5) Pesan yang disampaikannya cepat dan mudah diingat.

6) Mengembangkan pikiran dan pendapat para siswa

7) Mengembangkan imajinasi

8) Memperjelas hal-hal yang abstrak dan memberikan penjelasan yang lebih realistik

9) Mampu berperan sebagai media utama untuk mendokumentasikan realitas sosial yang akan dibedah di dalam kelas

10) Mampu berperan sebagai storyteller yang dapat memancing kreativitas peserta didik dalam mengekspresikan gagasannya.

Pada media pembelajaran video dalam satu kali pertemuan selama 30 menit anak dilatih untuk menulis tiga huruf saja. Video dibiarkan hidup dan secara menerus menunjukkan arah penulisan huruf.Anak dipersilahkan melihat, dan guru bertugas menghidupkan dan mematikan video.

Dalam kondisi belajar diskriminasi dan psikomotor, anak mengutamakan gerakangerakan tubuh, namun diperlukan pengamatan melalui alat-alat indera dan pengelola secara kognitif yang melibatkan pengetahuan dan permainan.

Berikut ini akan dijabarkan kondisi belajar diskriminasi dan psikomotor menurut
Gagne (1987) dalam media pembelajaran video

a) fase motivasi; guru mengenalkan dan menjelaskan terlebih dahulu konsep video, bentuk dan cara kerja

b) fase konsentrasi; akan diperkenalkan dengan bentuk tulisan yang terdapat pada video

c) fase pengolahan; video dihidupkan, anak menulis dilembar kerja (LK) Sesuai dengan petunjuk di video, kemudian anak mengerjakan latihan dilembar kerja(LK) sesuai, dengan petunjuk yang ada di video, selama berlatih video tetap dinyalakan untuk menunjukkan urutan dan arah penulisan

d) fase menggali; menggali "program mental" yang tersimpan dalam long term memori (dari ingatan) video dimatikan, anak diminta melakukan arah penulisan. Kemudian pada setiap permulaan anak diingatkan kembali carapenulisan yang telah dipelajari sebelumnya

e) fase umpan balik; guru memberikan penguatan baik secara lisan maupun tulisan untuk menilai pekerjaan anak.

Maimunah Hasan (2009: mengungkapkan bahwa kartu huruf adalah penggunaan sejumlah kartu sebagai alat bantu untuk belajar membaca dengan cara melihat dan mengingat bentuk huruf dan gambar yang disertai tulisan dari makna gambar pada kartu. Azhar Arsyad (2014:119) mengungkapkan bahwa kartu huruf adalah kartu abjad yang berisi gambar, huruf, tanda simbol, yang meningkatkan atau menuntun anak yang berhubungan dengan simbol-simbol tersebut.

Agus Hariyanto

(2009:84) mengungkapkan bahwa media pembelajaran kartu huruf adalah suatu cara dalam kegiatan pembelajaran untuk anak usia dini melalui kartu huruf. Kartu huruf yang digunakan berupa kartu yang terbuat dari karton berbentuk segi empat dan tiap kartu bertuliskan satu huruf kapital dan satu huruf kecil. Anak-anak belajar menulis huruf dari melihat simbol huruf pada kartu huruf.

Jadi berdasarkan penjelasan tersebut dapat ditegaskan bahwa media pembelajaran kartu huruf adalah suatu kegiatan dengan menggunakan alat berupa kartu huruf dari karton yang terdapat simbol huruf yang disertai tulisan sesuai dengan urutan dan arah yang benar, dengan tujuan meningkatkan kemampuan menulis huruf pada anak usia dini. Metode yang sering digunakan adalah metode ceramah atau bercakap cakap. 
Metode yang menggunakan percakapan dalam bentuk tanya jawab ini sebaiknya dilakukan dengan banyak arah yaitu tanya jawab antara anak dengan anak, dan antara anak dengan guru. Dengan demikian, bercakap-cakap di sini sudah berkembang menjadi suatu dialog bahkan akan bersifat diskusi karena sudah dapat melibatkan dua orang atau lebih. (Montolalu, dkk: 2009:10.23).

Sedangkan Moeslichatoen (2004: 91-92) mengatakan bahwa metode ceramah atau bercakap-cakap merupakan salah satu bentuk komunikasi antarpribadi. Berkomunikasi merupakan proses dua arah. Untuk terjadinya komunikasi dalam percakapan diperlukan keterampilan mendengar dan keterampilan berbicara. Untuk bercakap-cakap secara efektif, belajar mendengarkan dan belajar berbicara sama pentingnya. Dalam bercakap-cakap tiap anak yang terlibat dalam kegiatan itu ingin membicarakan segala sesuatu yang diketahui, dimiliki, dan yang dialami kepada anak lain atau gurunya. Kejelasan pemahaman tentang kartu huruf memungkinkan anak dapat menanggapi perintah, menjawab pertanyaan, mengikuti urutan peristiwa yang dilakukan, menambah informasi, dan sebagainya.

Kelebihan media kartu huruf menurut R. Ibrahim; Nana Syaodih S. (2003:114) adalah sebagai berikut:

1) Mudah di bawa-bawa: Dengan ukuran yang kecil sehingga membuat mediakartu huruf dapat disimpan di tas bahkan di saku, sehingga tidakmembutuhkan ruang yang luas, dapat digunakan dimana saja, di kelasataupun di luar kelas.

2) Praktis: dilihat dari cara pembuatan dan penggunaannya, media kartu hurufsangat praktis, dalam menggunakan media ini guru tidak perlu memilikikeahlian khusus, media ini tidak perlu juga membutuhkan listrik. Jika akan menggunakan kita tinggal menyusun urutan gambar sesuai dengan keinginankita, pastikan posisi gambarnya tepat tidak terbalik, dan jika sudah digunakantinggal disimpan kembali dengan cara diikat atau menggunakan kotak khusussupaya tidak tercecer. Selain itu biaya pembuatan media kartu huruf ini pun sangatlah murah, karena dapat menggunakan barang-barang bekas sepertikertas kardus sebagai kartunya.

3) Gampang diingat: karakteristik media kartu huruf adalah menyajikan huruf-huruf pada setiap kartu yang disajikan. Sajian hurufhuruf dalam kartu iniakan memudahkan siswa untuk mengingat dan menghafal bentuk huruftersebut.

4) Menyenangkan: media kartu huruf dalam penggunannya bisa melalui permainan. Misalnya siswa secara $b$ erlomba-lomba mencari satu kartu yang bertuliskan huruf tertentu ya ng disimpan secara acakdengan cara berlaris iswa berlomba untuk mencari sesuai perintah. Selain mengasah kemampuankognitif juga melatih ketangkasan (fisik).

Berdasarkan teori di atas, dapat disimpulkan langkah-langkah yang dilakukan oleh guru dalam penggunaan media pembelajaran kartu huruf adalah sebagai berikut:

1) Anak diperkenalkan terlebih dahulu kartu huruf secara berurutan melalui papan flannel

2) Guru menempelkan kartu huruf tersebut di papan flannel dan menyebutkanya secara berulang-ulang cara penulisannya dengan urutan dan arah yang mudah setelah diberikan contoh dan latihan sambil menjelaskan penulisan di lembar kerja (LK)

3) Guru menuliskanhuruf di papan tulis sesuai huruf dipapan flanel satu huruf

4) Guru menanyakan kembali setiap kartu huruf yang telah dijelaskan kepada anak

5) Guru menugaskan anak menulis bentuk huruf di lembar kerja (LK) dalam bentuk latihan seperti huruf yang jelaskan guru di papan flannel.

Dari uraian diatas dapat disimpulkan secara jelas perbedaan media pembelajaran kartu huruf dan media pembelajaran video, yang dapat dilihat dari tabel 1 dibawah ini:

Tabel 1. Perbedaan Media Pembelajaran Kartu Huruf dengan Media Pembelajaran Video

\begin{tabular}{llc}
\hline No & \multicolumn{1}{c}{ Media Pembelajaran Kartu Huruf } & \multicolumn{1}{c}{ Media Pembelajaran Video } \\
\hline 1 & $\begin{array}{l}\text { Pengenalan huruf diberikan melalui kartu } \\
\text { huruf di papan flannel }\end{array}$ & Pengenalan huruf diberikan melalui video \\
\hline 2 & $\begin{array}{l}\text { Cara penulisan dicontohkan oleh guru di } \\
\text { papan tulis sesuai dengan kartu huruf di } \\
\text { papan planel. }\end{array}$ & Cara penulisan dicontohkan oleh video \\
&
\end{tabular}




\begin{tabular}{llll}
\hline 3 & $\begin{array}{l}\text { Tigahuruf yang diajarkan untuk satu kali } \\
\text { pertemuan }\end{array}$ & $\begin{array}{l}\text { Tigahuruf yang diajarkan untuk satu kali } \\
\text { pertemuan }\end{array}$ \\
\hline 4 & $\begin{array}{l}\text { Kegiatan pembelajaran monoton dan } \\
\text { terfokus pada guru }\end{array}$ & $\begin{array}{l}\text { Kegiatan pembelajaran dinamis antara guru, } \\
\text { video dan anak }\end{array}$ & $\begin{array}{l}\text { Disusun berdasarkan kondisi belajar } \\
\text { diskriminasi dan keterampilan motorik }\end{array}$ \\
\hline 5 & $\begin{array}{l}\text { Disusun berdasarkan kondisi belajar } \\
\text { diskriminasi dan konsep konkret }\end{array}$ & Penilaian pada keterampilan proses \\
\hline 6 & Penilaian pada hasil & &
\end{tabular}

Dari uraian di atas dapat disimpulkan bahwa media pembelajaran kartu huruf merupakan sumber belajar yang menggunakan kertas huruf dari karton tebal yang bertujuan merangsang perhatian dan kemauan anak PAUD belajar menulis huruf secara efektif dan efisien.

Budiningsih (2005:34) menyebutkan bahwa Teori Belajar Kognitif lebih mementingkan proses belajar daripada hasil belajarnya. Kreativitas merupakan bakat yang secara potensial dimiliki oleh setiap orang dapat diidentifikasikan dan dipupuk melalui pendidikan yang tepat. Hawadi (2001:3) mengemukakan bahwa kreativitas merupakan suatu bidang kajian yang kompleks, yang menimbulkan berbagai perbedaan pandangan. Perbedaan tersebut terletak pada bagaimana kreativitas itu didefinisikan. Adapun kreativitas didefinisikan, sangat berkaitan dengan penekanan pendefinisian dan tergantung pada dasar teori yang menjadi dasar acuannya.

Sementara itu, Jamaris (2006:59) memaparkan bahwa kreativitas merupakan kemampuan seseorang untuk mengendalikan tekanan regresi yang dialaminya.Selain itu, Munandar (1999:28) mengatakan kreativitas adalah kemampuan untuk membuat kombinasi baru, berdasarkan data, informasi, atau unsurunsur yang ada.Secara operasional kreativitas dapat dirumuskan sebagai kemampuan yang mencerminkan kelancaran, keluwesan dan orisinalitas dalam berpikir serta kemampuan untuk mengelaborasikan (mengembangkan, memperkaya, memperinci suatu gagasan). Definisi pribadi dikemukakan oleh Stenberg (1988) bahwa kreativitas merupakan titik pertemuan yang khas antara tiga atribut psikologis, intelegensi, gaya kognitif dan kepribadian/motivasi. Secara bersamaan ketigadalam alam pikiran ini .
Kreativitas dapat diukur dengan cara mengidentifikasi kemampuan berpikir kreatif yang dimiliki yaitu:

a) Fluency (kelancaran) yaitu kemampuan mengemukakan ide-ide yang serupa untuk memecahkan suatu masalah.

b) Flexibility (keluwesan) yaitu kemampuan untuk menghasilkan berbagai macam ide guna memecahkan suatu masalah di luar kategori yang biasa.

c) Originality (keaslian) yaitu kemampuan memberikan respon yang unik atau luar biasa

d) Elaboration (keterperincian) yaitu kemampuan menyatakan pengarahan ide secara terperinci untuk mewujudkan ide tersebut menjadi kenyataan.

Agar anak bisa berpikir kreatif, ia haruslah bisa bersikap terbuka dan fleksibel dalam mengemukakan gagasan. Makin banyak ide yang dicetuskannya menandakan makin kreatif si anak.

Dalam penelitian ini untuk mengukur tingkat kreativitas anak digunakan tes yang mengukur kreativitas secara langsung yaitu Tes Kreativitas Figural (TKF). Adapun unsur penilaian berpikir kreatif adalah sebagai berikut: 1. Fleksibel (Keluwesan)

Anak mampu memberikan jawaban yang berbeda-beda.Untuk gambar lingkaran, contohnya, anak mengasosiasikannya sebagai piring, bulan, bola, telur dadar dan sebagainya.Anak juga diminta untuk membuat sebanyak mungkin objek mati maupun hidup pada gambar lingkaran tadi.Namun, tes kreativitas ini bukan dimaksudkan sebagai tes menggambar, melainkan sebagai tes gagasan, sehingga unsur "keindahan" tidak diprioritaskan.

2. Orisinalitas (keaslian)

Anak mampu memberikan jawaban yang jarang/lhuruf dan berbeda dengan jawaban anak lain pada umumnya. Dari bentuk 
lingkaran yang sama, contohnya, anak mahir menggambarkannya sebagai wajah orang.

3. Elaborasi (keterperincian)

Anak mampu memberikan jawaban secara rinci sekaligus mampu memperkaya dan mengembangkan jawaban tersebut.Dia bisa melengkapi gambar wajah tersebut dengan mata, hidung, bibir, telinga, leher, rambut sampai aksesoris semisal kalung dan jepit rambut. Makin detail ornament atau organorgan yang digambarkannya, berarti mencirikan ia anak yang kreatif. "Jadi, anak kreatif tak sekedar mengemukakan ide, tapi juga dapat mengembangkan gagasan yang dilontarkannya. Untuk mengukur: aspek kelancaran, kelenturan, orisinalitas, dan elaborasi dari kemampuan berpikir kreatif dengan cara memberi skor pada gambargambar yang dibuat oleh anak itu sendiri. Dari sinilah dihitung skor totalnya dan diklasifikasikan kreativitas tinggi dan rendah.Adapun kriteria penilaian dengan menggunakan alat tes kreativitas yang dirancang oleh psikolog dengan menggunakan instrument dalam bentuk figural.

Dalam penelitian ini, klasifikasi skor kreativitas peserta didik dibagi psikolog kedalam dua kategori yaitu:

1) Skor $\geq 30$ kategori tinggi

2) Skor $\leq 29$ kategori rendah

\section{METODE PENELITIAN}

Penelitian ini dilaksanakan di PAUD Kenanga Raya pada semester ganjil, dalam rentang waktu 10 (sepuluh) kali pertemuan sesuai dengan jadwal pelajaran menulis huruf dan untuk satu kali pertemuan digunakan waktu 30 menit. Populasi penelitian ini adalah seluruh anak usia dini yang ada di PAUD Kenanga Raya yang berjumlah 60. Arikunto (2006) mengemukakan bahwa sampel adalah sebagian wakil populasi yang diteliti. Selanjutnya dari populasi penelitian dipilih sampel secara acak (cluster random sampling). Ditentukan kelas A sebagai kelas eksperimen (kelas yang diberi perlakuan dengan menggunaan media pembelajaran video) dengan jumlah sampel 20 orang dan kelas B dengan jumlah sampel 20 orangsebagai kelas kontrol (kelas yang menggunakan media pembelajaran kartu huruf). Jadi seluruh sampel penelitian adalah 40 orang anak.

Penelitian ini menggunakan metode eksperimen dengan rancangan quasi eksperimen desain faktorial $2 \times 2$. Melalui desain ini akan dibandingkan pengaruh media pembelajaran video dan media pembelajaran kartu huruf. Dimana melalui penelitian ini akan dibandingkan pengaruh antara media pembelajaran video dan kartu hurufterhadap kemampuan menulis huruf anak PAUD ditinjau dari tingkat kreativitas tinggi dan kreativitas rendah.

Adapun rancangan eksperimen dalam penelitian sebagaimana yang ditunjukkan pada tabel 2 berikut:

Tabel 2. Rancangan Penelitian Faktorial 2 x 2

\begin{tabular}{lcc}
\hline Media Pembelajaran $(A)$ & $\begin{array}{c}\text { Media Pembelajaran } \\
\text { Video }\left(\mathbf{A}_{1}\right)\end{array}$ & $\begin{array}{c}\text { Media Pembelajaran } \\
\text { Kartu Huruf }\left(\mathrm{A}_{2}\right)\end{array}$ \\
Kreativitas $(\mathbf{B})$ & $\mathrm{A}_{1} \mathrm{~B}_{1}$ & $\mathrm{~A}_{2} \mathrm{~B}_{1}$ \\
\hline Kreativitas Tinggi $\left(\mathbf{B}_{1}\right)$ & $\mathrm{A}_{1} \mathrm{~B}_{2}$ & $\mathrm{~A}_{2} \mathrm{~B}_{2}$ \\
\hline Kreativitas Rendah $\left(\mathbf{B}_{2}\right)$ & &
\end{tabular}

Keterangan:

A $=$ Media Pembelajaran

$\mathrm{A}_{1}=$ Media Pembelajaran Video

$\mathrm{A}_{2}=$ Media Pembelajaran Kartu Huruf

$\mathrm{B}=$ Kreativitas

$\mathrm{B}_{1}=$ Kreativitas Tinggi

$\mathrm{B}_{2}=$ Kreativitas Rendah
$\mathrm{A}_{1} \mathrm{~B}_{1}=$ Rata-rata kemampuan menulis huruf anak PAUD yang menggunakan media pembelajaran video dengan kreativitas tinggi

$\mathrm{A}_{2} \mathrm{~B}_{1}=$ Rata-rata kemampuan menulis huruf anak PAUD yang menggunakan media pembelajaran kartu huruf dengan kreativitas tinggi 
$\mathrm{A}_{1} \mathrm{~B}_{2}=$ Rata-rata kemampuan menulis huruf anak PAUD yang menggunakan media pembelajaran video dengan kreativitas rendah

$\mathrm{A}_{2} \mathrm{~B}_{2}=$ Rata-rata kemampuan menulis huruf anak PAUD yang menggunakan media pembelajaran kartu huruf dengan kreativitas rendah.

Teknik analisis data yang dilakukan dalam penelitian ini adalah teknik analisis varians (ANAVA) pengujian hipotesis dilakukan pada taraf signifikansi $5 \%$. Jika dalam pengujian ANAVA terdapat interaksi penggunaan media pembelajaran dan kreativitas terhadap kemampuan menulis huruf anak PAUD maka dilanjutkan dengan uji lanjut. Jika jumlah sampel tiap sel sama (n sama) maka uji lanjut dilakukan dengan uji Tukey dan jika jumlah sampel pada sel berbeda ( $\mathrm{n}$ berbeda), maka untuk uji lanjut digunakan uji scheffe. Sebagai uji persyaratan analisis dilakukan pengujian normalitas dengan menggunakan uji liliefors.Setelah uji normalitas dilakukan uji homogenitas dengan menggunakan uji $\mathrm{F}$ dan uji Barlett. Adapun hipotesis yang diuji adalah:

Hipotesis $1: \mathrm{H}_{0}: \mu \mathrm{A}_{1=} \mu \mathrm{A}_{2}$

$$
\mathrm{H}_{\mathrm{a}}: \mu \mathrm{A}_{1}>\mu \mathrm{A}_{2}
$$

Hipotesis $2: \mathrm{H}_{0}: \mu \mathrm{B}_{1=} \mu \mathrm{B}_{2}$

$$
\mathrm{H}_{\mathrm{a}}: \mu \mathrm{B}_{1}>\mu \mathrm{B}_{2}
$$

Hipotesis $3: \mathrm{H}_{0}: \mathrm{A}_{1} \mathrm{x} \mathrm{B}_{2}=0$

$$
\mathrm{H}_{\mathrm{a}}: \mathrm{B}_{1} \times \mathrm{B}_{2} \neq 0
$$

dimana :

$\mu \mathrm{A}_{1}=$ Rata-rata kemampuan menulis huruf anak PAUD yang diajarkan dengan media pembelajaran video.

$\mu \mathrm{A}_{2}=$ Rata-rata kemampuan menulis huruf anak PAUD yang diajarkan dengan media pembelajaran kartu huruf.

$\mu \mathrm{B}_{1}=$ Rata-rata kemampuan menulis huruf anak PAUD yang memiliki kreativitas tinggi.

$\mu B_{2}=$ Rata-rata kemampuan menulis huruf anak PAUD yang memiliki kreativitas rendah.

$\mathrm{A}_{1} \times \mathrm{B}_{2}=$ Interaksi antara media pembelajaran dengan kreativitas.

$\mathrm{A}=$ Media Pembelajaran

$\mathrm{B}=$ Kreativitas

\section{HASIL PENELITIAN \\ Hasil}

Berdasarkan data skor kemampuan menulis huruf anak PAUD, langkah berikutnya adalah menghitung total skor dan rata-rata skor tiap kelompok perlakuan menurut tabel ANAVA, yang selanjutnya dapat digunakan sebagai dasar keputusan statistik untuk pengujian hipotesis:

Tabel 3. Rangkuman Hasil Perhitungan Statistik Dasar untuk ANAVA 2 Jalur

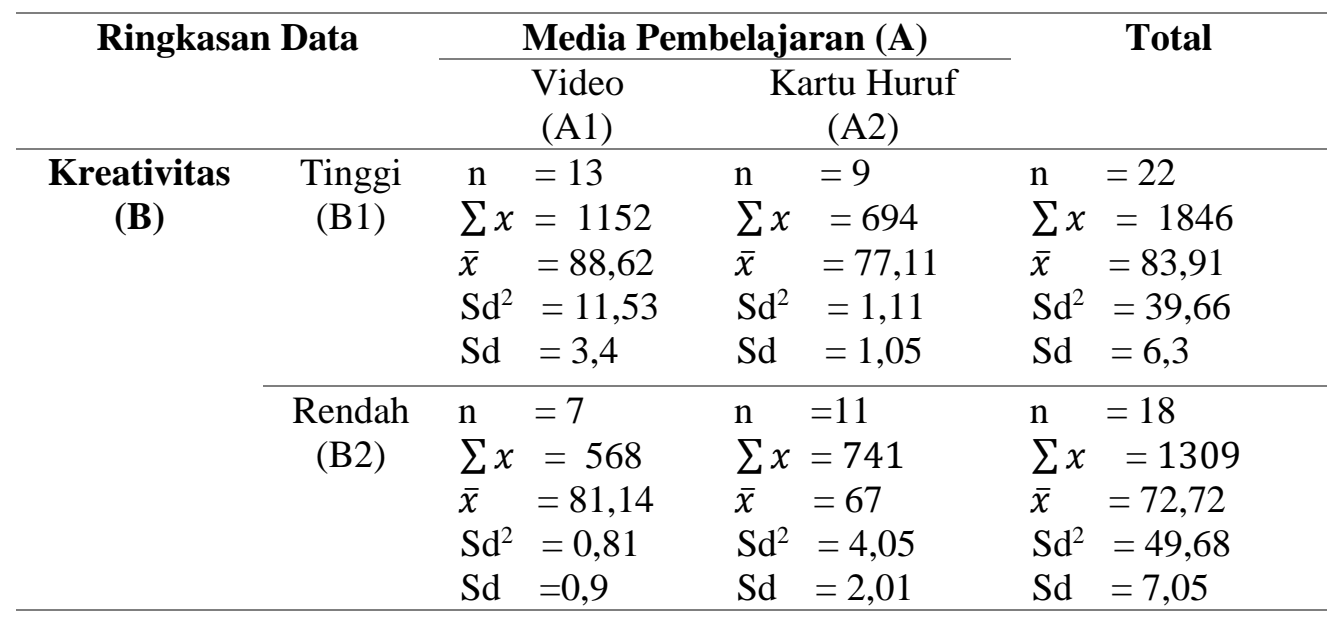




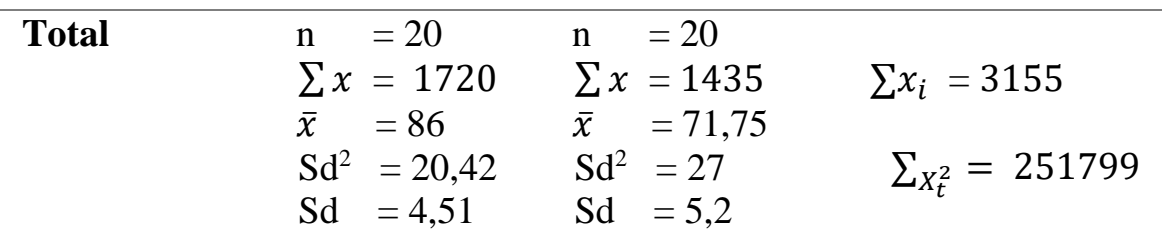

\section{Pengujian Hipotesis}

Secara keseluruhan hasil ANAVA untuk pengujian hipotesis dapat dilihat pada tabel 4.12 dibawah ini :

Tabel 4. Ringkasan Hasil Analysis of Varians Gabungan

\begin{tabular}{ccccccc}
\hline $\begin{array}{c}\text { Sumber } \\
\text { Varians }\end{array}$ & JK & dK & RJK & Fh & $\begin{array}{c}\text { Ft }(\boldsymbol{\alpha}=\mathbf{0 , 0 5}) \\
(\mathbf{1 , 3 5})\end{array}$ & Ket \\
\hline Antar Kolom & 2030,62 & 1 & 2030,62 & 378,14 & 4,12 & Signifikan \\
\hline Antar Baris & 238,95 & 1 & 238,95 & 44,5 & 4,12 & Signifikan \\
\hline Interaksi & 485,43 & 1 & 485,43 & 90,4 & 4,12 & Signifikan \\
\hline Galat & 193,4 & 35 & 5,37 & & 4,12 & \\
\hline Total & 2948,4 & 38 & & & & \\
\hline
\end{tabular}

Untuk mengetahui interaksi antara kreativitas dalam mempengaruhi kemampuan menulis huruf dilakukan uji lanjut yang diajarkan dengan Uji Scheffe. Ringkasan hasil Uji Scheffe dapat dilihat pada Tabel 4.13 berikut.

Tabel 5. Ringkasan Hasil Perhitungan Uji Scheffe

\begin{tabular}{cccccc}
\hline No. & \multicolumn{2}{l}{ Hasil Uji Lanjut } & $\mathbf{F}_{\text {hitung }}$ & $\mathbf{F}_{\text {tabel }(\mathbf{0 , 0 5})}$ & Keterangan \\
\hline 1 & $\mathrm{~F}_{\mathrm{A} 1 \mathrm{~B} 1}$ & $\mathrm{~F}_{\mathrm{A} 1 \mathrm{~B} 2}$ & 6,9 & 3,24 & Signifikan \\
\hline 2 & $\mathrm{~F}_{\mathrm{A} 2 \mathrm{~B} 1}$ & $\mathrm{~F}_{\mathrm{A} 2 \mathrm{~B} 2}$ & 9,5 & 3,24 & Signifikan \\
\hline 3 & $\mathrm{~F}_{\mathrm{A} 1 \mathrm{~B} 1}$ & $\mathrm{~F}_{\mathrm{A} 2 \mathrm{~B} 1}$ & 11,4 & 3,24 & Signifikan \\
\hline 4 & $\mathrm{~F}_{\mathrm{A} 1 \mathrm{~B} 2}$ & $\mathrm{~F}_{\mathrm{A} 2 \mathrm{~B} 2}$ & 12,74 & 3,24 & Signifikan \\
\hline 5 & $\mathrm{~F}_{\mathrm{A} 1 \mathrm{~B} 1}$ & $\mathrm{~F}_{\mathrm{A} 2 \mathrm{~B} 2}$ & 22,52 & 3,24 & Signifikan \\
\hline 6 & $\mathrm{~F}_{\mathrm{A} 1 \mathrm{~B} 2}$ & $\mathrm{~F}_{\mathrm{A} 2 \mathrm{~B} 1}$ & 3,47 & 3,24 & Signifikan \\
\hline
\end{tabular}

Data hasil perhitungan pengujian hipotesisnya dijabarkan sebagai berikut :

1. Perbandingan kelompok $A_{1} B_{1}$ dengan $A_{2} B_{1}$ diperoleh $\mathrm{F}_{\text {hitung }}>\mathrm{F}_{\text {tabel }}$ sehingga memberikan keputusan menerima Ha. Dengan demikian, hipotesis yang menyatakan bahwa rata-rata hasil tes kemampuan menulis huruf anak yang memiliki kreativitas tinggi, diberikan pembelajaran yang diajarkan dengan media pembelajaran video lebih tinggi daripada kemampuan menulis huruf anak yang memiliki kreativitas tinggi yang diberikan pembelajaran yang diajarkan dengan media pembelajaran kartu huruf, teruji kebenarannya. Hal ini membuktikan bahwa kemampuan menulis huruf anak yang memiliki kreativitas tinggi akan berkembang secara signifikan apabila diberikan kesempatan belajar yang diajarkan dengan media pembelajaran video karena lebih terstimulasi potensi, bakat dan kemauannya.

2. Perbandingan kelompok $A_{1} B_{1}$ dengan $A_{1} B_{2}$ diperoleh $F_{\text {hitung }}>F_{\text {tabel }}$ sehingga memberikan keputusan menerima Ha. Dengan demikian, hipotesis yang menyatakan bahwa rata-rata hasil tes kemampuan menulis huruf anak yang memiliki kreativitas tinggi, diberikan pembelajaran yang diajarkan dengan media 
pembelajaran video lebih tinggi daripada kemampuan menulis huruf anak yang memiliki kreativitas rendah yang diberikan pembelajaran yang diajarkan dengan media pembelajaran video, teruji kebenarannya. Hal ini membuktikan bahwa kemampuan menulis huruf anak yang memiliki kreativitas tinggi akan berkembang secara signifikan apabila diberikan kesempatan belajar yang diajarkan dengan media pembelajaran video, sebaliknya anak dengan kreativitas rendah akan kesulitan belajar yang diajarkan dengan media pembelajaran video karena anak seakan terpaksa dan tidak memiliki minat dan kemauan yang kuat dalam menulis huruf.

3. Perbandingan kelompok $\mathrm{A}_{1} \mathrm{~B}_{1}$ dengan $\mathrm{A}_{2} \mathrm{~B}_{2}$ diperoleh $\mathrm{F}_{\text {hitung }}<\mathrm{F}_{\text {tabel }}$ sehingga memberikan keputusan menolak Ha. Dengan demikian, hipotesis yang menyatakan bahwa rata-rata hasil tes kemampuan menulis huruf anak yang memiliki kreativitas tinggi, diberikan pembelajaran yang diajarkan dengan media pembelajaran video tidak lebih tinggi daripada kemampuan menulis huruf anak yang memiliki kreativitas rendah yang diberikan pembelajaran yang diajarkan dengan media pembelajaran kartu huruf, teruji kebenarannya. Hal ini membuktikan bahwa kemampuan menulis huruf anak yang memiliki kreativitas tinggi akan berkembang secara signifikan apabila diberikan kesempatan belajar dengan mengunakan media pembelajaran video dan anak yang memiliki kreativitas rendah akan berkembang juga yang diajarkan dengan media pembelajaran kartu huruf karena masing-masing metode sama baiknya bagi kedua kelompok anak dimana dia senang dengan apa yang dia lakukan.

4. Perbandingan kelompok $\mathrm{A}_{2} \mathrm{~B}_{1}$ dengan $\mathrm{A}_{1} \mathrm{~B}_{2}$ diperoleh $\mathrm{F}_{\text {hitung }}>\mathrm{F}_{\text {tabel }}$ sehingga memberikan keputusan menerima Ha. Dengan demikian, hipotesis yang menyatakan bahwa rata-rata hasil tes kemampuan menulis huruf anak yang memiliki kreativitas tinggi diberikan pembelajaran yang diajarkan dengan media pembelajaran kartu huruf lebih tinggi daripada kemampuan menulis huruf anak yang memiliki kreativitas rendah yang diberikan pembelajaran yang diajarkan dengan media pembelajaran video, teruji kebenarannya. Hal ini membuktikan bahwa kemampuan menulis huruf anak yang memiliki kreativitas tinggi apabila belajar yang diajarkan dengan media pembelajaran kartu huruf memang lebih baik sedikit dibanding anak yang memiliki kreativitas rendah apabila belajar yang diajarkan dengan media pembelajaran video tetapi sebenarnya mereka bermain pada zona yang mereka tidak senangi sehingga tidak terstimulasi dengan baik

5. Perbandingan kelompok $A_{2} B_{1}$ dengan $A_{2} B_{2}$ diperoleh $F_{\text {hitung }}>F_{\text {tabel }}$ sehingga memberikan keputusan menerima Ha. Dengan demikian, hipotesis yang menyatakan bahwa rata-rata hasil tes kemampuan menulis huruf anak yang memiliki kreativitas tinggi, diberikan pembelajaran yang diajarkan dengan media pembelajaran kartu huruf lebih tinggi daripada kemampuan menulis huruf anak yang memiliki kreativitas rendah yang diberikan pembelajaran yang diajarkan dengan media pembelajaran kartu huruf, teruji kebenarannya. Hal ini membuktikan bahwa anak yang memiliki kreativitas rendah apabila belajar yang diajarkan dengan media pembelajaran kartu huruf akan lebih berkembang kemampuan menulis hurufnya secara signifikan karena dia senang melakukannya sehingga terstimulasi dengan baik.

6. Perbandingan kelompok $\mathrm{A}_{2} \mathrm{~B}_{2}$ dengan $\mathrm{A}_{1} \mathrm{~B}_{2}$ diperoleh $F_{\text {hitung }}>F_{\text {tabel }}$ sehingga memberikan keputusan menerima Ha. Dengan demikian, hipotesis yang menyatakan bahwa rata-rata hasil tes kemampuan menulis huruf anak yang memiliki kreativitas rendah, diberikan pembelajaran yang diajarkan dengan media pembelajaran kartu huruf lebih tinggi daripada kemampuan menulis huruf anak yang memiliki kreativitas rendah yang diberikan pembelajaran yang diajarkan dengan media pembelajaran video, teruji kebenarannya. Hal ini membuktikan bahwa kemampuan menulis huruf anak yang memiliki kreativitas rendah akan berkembang secara signifikan apabila diberikan kesempatan belajar yang diajarkan dengan media pembelajaran kartu huruf 
dibanding diberikan kesempatan belajar yang diajarkan dengan media pembelajaran video karena anak dengan kreativitas rendah lebih berminat yang diajarkan dengan media pembelajaran kartu huruf sehingga terstimulasi potensi, bakat dan kemauanya dengan baik.

Maka perlu diberikan gambaran grafik estimasi yang menunjukkan adanya interaksi tersebut.

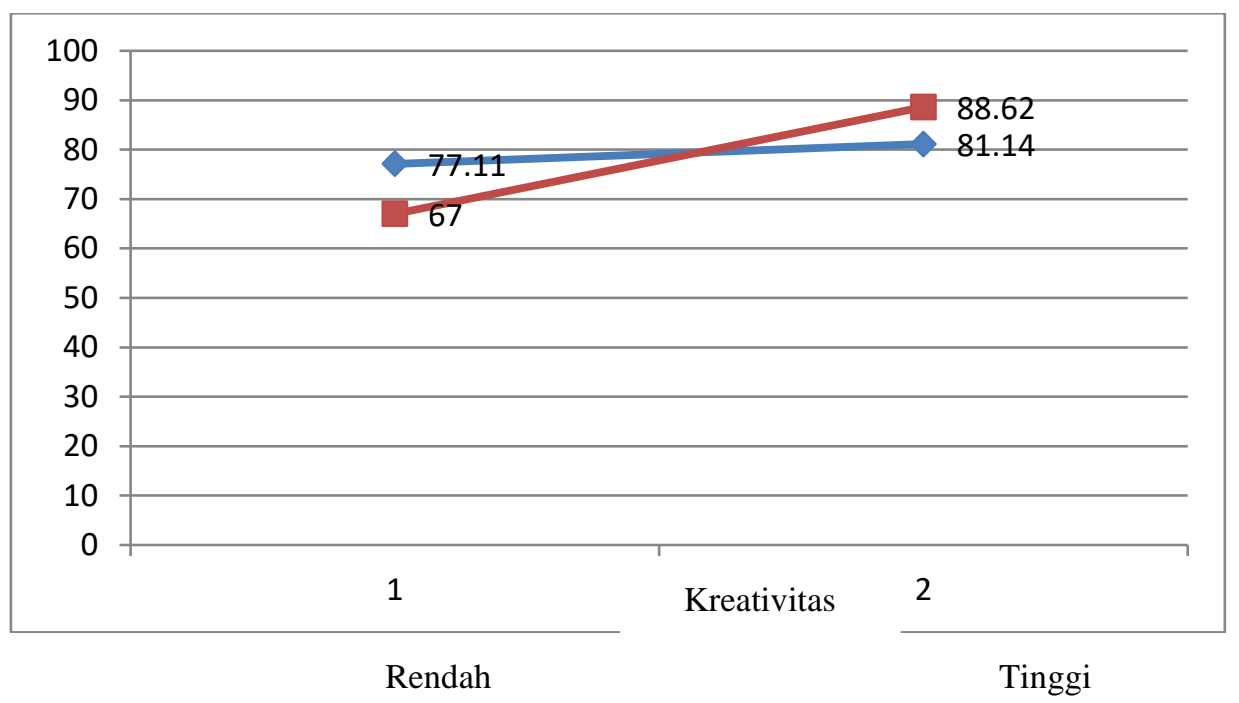

\section{Keterangan Gambar :—— Media Pembelajaran Kartu Huruf Media Pembelajaran Video}

\section{Pembahasan}

Berdasarkan hasil penelitian rata-rata kemampuan menulis anak dapat dijelaskan seperti berikut :

1. Pembelajaran yang diajarkan dengan media pembelajaran video memberikan kesempatan kepada anak untuk dapat melihat dan mengekspresikan pikiran kepada teman sebayanya sehingga kemampuan menulis anak dapat meningkat. Dalam pembelajaran yang diajarkan dengan media pembelajaran kartu huruf anak lebih banyak diberikan kartu huruf secara berulang-ulang sehingga membuat anak bosan. Anak juga sulit mengingat kembali huruf dan cara penulisannya. Hal ini sejalan dengan pendapat Vigotsky dalam Schickedanz (2001) dengan teori konstruktivisme yang menjelaskan bahwa perkembangan bahasa termasuk menulis dibentuk dari interaksi dengan orang lain dan dengan berinteraksi maka pengetahuan, nilai dan sikap anak akan berkembang. Anak memiliki perkembangan kognisi yang terbatas pada usia-usia tertentu, tetapi melalui interaksi sosial, anak akan mengalami peningkatan kemampuan berpikir. Kemampuan menulis anak juga akan dapat meningkat dengan baik apabila didukung dengan lingkungan yang kaya dengan pembelajaran bahasa.

2. Pembelajaran yang diajarkan dengan media pembelajaran video memberi tantangan yang cukup besar pada anak untuk melakukan aktivitas belajar sesuai dengan kemampuannya dengan bisa melakonkan orang lain atau diri sendiri berdasarkan pengalaman mainnya. Untuk anak yang memiliki kreativitas tinggi kemampuan menulisnya lebih tinggi dibanding dengan anak yang memiliki kreativitas rendah. Hal ini terjadi karena beberapa hal. Pertama, anak yang memiliki kreativitas tinggi telah memiliki kepercayaan diri sehingga kesempatan dalam menulis huruf akan memberikan kesempatan pada anak untuk dapat berekspresi mengeluarkan ide-ide atau gagasan yang diimplementasikan dalam bentuk tindakan dengan mencoret-coret atau 
membentuk garis yang merupakan tahap awal menulis. Sebaliknya anak yang memiliki kreativitas rendah, karena memiliki harga diri yang rendah, kesulitan dalam berekspresi. Hal ini sejalan dengan pendapat Ali (2009) yang mengatakan bahwa kreativitas membuka pikiran dan menjadikan motivasi hidup lebih tinggi. Kedua, anak yang memiliki kreativitas tinggi menyukai tantangan sehingga dalam kegiatan menulis huruf yang sudah dirancang membuat dia semangat untuk melakukannya bahkan akan bisa berimprovisasi dengan alat dan bahan main yang ada karena ada keyakinan tentang dirinya sendiri, untuk anak yang memiliki kreativitas rendah kurang dapat berimprovisasi karena umumnya hanya menerima saja apa yang diberikan Ibu guru dan kurang ada keyakinan terhadap diri sendiri.

3. Anak yang memiliki kreativitas tinggi akan lebih baik apabila diberikan lebih banyak kesempatan menggunakan media pembelajaran video dan untuk anak yang memiliki kreativitas rendah lebih baik diberi lebih banyak kesempatan menggunakan media pembelajaran kartu huruf karena di media pembelajaran video memberi tantangan dan keinginan lebih tinggi daripada media pembelajaran kartu huruf sehingga anak melakukan kegiatan dilandasi oleh keinginan dan kemauannya sendiri, guru hanya tinggal memfasilitasi saja. Umumnya anak akan senang apabila dia bermain sesuai dengan keinginan dan kebutuhannya sehingga apabila anak bermain dengan dilandasi perasaan suka dan senang maka itulah yang terbaik untuk anak sehingga bisa merangsang kemampuan menulis ketingkat yang lebih tinggi. Guilford dalam Hurlock (1998) menekankan pentingnya kemampuan berpikir kreatif dalam pendidikan yang merupakan salah satu bentuk kreativitas.

Selanjutnya anak yang memiliki kreativitas rendah perlu terus dimotivasi oleh para guru sehingga semakin memiliki kepercayaan diri yang baik karena kreativitas sebenarnya dapat berubah ke arah yang lebih baik apabila anak mendapat dukungan dari lingkungan sekitarnya sehingga dia berani melakukan dan menyatakan sesuatu yang akhirnya kemampuan menulisnya juga akan bisa lebih meningkat.

\section{PENUTUP}

Berdasarkan hasil analisis data dan pengujian hipotesis penelitian yang telah dikemukakan, dapat ditarik beberapa simpulan sebagai berikut:

Pertama, kemampuan menulis huruf anak PAUD yang mengikuti pembelajaran dengan media pembelajaran video lebih tinggi daripada anak yang mengikuti pembelajaran dengan menggunakan media pembelajaran kartu huruf. Dengan demikian dapat dikatakan bahwa media pembelajaran video lebih efektif digunakan untuk meningkatkan kemampuan menulis huruf anak daripada pembelajaran dengan media pembelajaran kartu huruf.

Kedua, anak yang memiliki kreativitas tinggi kemampuan menulis lebih tinggi dibanding dengan anak yang memiliki kreativitas rendah pada kegiatan pembelajaran dengan media pembelajaran video. Dengan demikian untuk meningkatkan kemampuan menulis huruf anak yang memiliki kreativitas tinggi sebaiknya dilakukan melalui pembelajaran dengan media pembelajaran video. Sebaliknya anak yang memiliki kreativitas rendah, skor kemampuan menulis huruf lebih tinggi dibanding dengan anak yang memiliki kreativitas tinggi pada kegiatan pembelajaran dengan media pembelajaran kartu huruf. Dengan demikian dapat dinyatakan bahwa untuk meningkatkan kemampuan menulis anak yang memiliki kreativitas rendah sebaiknya dilakukan melalui pembelajaran dengan media pembelajaran kartu huruf.

Ketiga, terdapat pengaruh interaksi antara pembelajaran dengan kreativitas terhadap kemampuan menulis huruf anak PAUD sehingga kreativitas anak perlu terus ditingkatkan oleh guru dengan jalan melatih anak untuk terus kreatif dan terlibat aktif.

Dengan demikian dapat dinyatakan bahwa untuk meningkatkan kemampuan menulis huruf anak PAUD dapat dilakukan melalui pembelajaran dengan menggunakan media pembelajaran, khususnya media pembelajaran video.

\section{DAFTAR PUSTAKA}

Arikunto, Suharsimi (2006). Prosedur Penelitian: suatu pendekatan praktek edisi revisi. Jakarta: Rineka Cipta

Arsyad, Azhar. (2014). Media Pembelajaran. Jakarta: Rajawali Press 
Budiningsih, C. Asri. (2005). Belajar dan Pembelajaran. Jakarta: Rineka Cipta

Djamarah, Syaiful Bahri. (2002). Psikologi Belajar. Jakarta: Rineka Cipta

Gagne, M.R. (1987). The Condition of Learning. USA: Holt, Rine Hart and Wiston

Hasan, Maimunah. (2009). PAUD (Pendidikan Anak Usia Dini). Jogyakarta: Diva Press

Hasnida. (2015). Media Pembelajaran Kreatif. Jakarta: Luxima

Hawadi, R.A, Wihardjo, R.S.D., dan Wiyono,M. (2001). Kreativitas. Jakarta: Grasindo

Ibrahim, R.; Nana Syaodih S. (2003). Perencanaan Pengajaran. Jakarta: Asdi Mahasatya

Jainab. (2004). Pengaruh Strategi Pembelajaran Audio Visual dan Kreativitas terhadap Kemampuan Menulis Angka Anak Taman Kanak-kanak. Tesis. Medan: Program Pascasarjana Universitas Negeri Medan

Jamaris, Martini. (2006). Perkembangan dan Pengembangan Anak Usia Taman Kanakkanak. Jakarta: Grasindo

Majid, Abdul. (2006). Perencanaan Pembelajaran: Mengembangkan Standar Kompetensi Guru. Bandung: Rosdakarya

Moeslichatoen, R. (2004). Metode Pengajaran di Taman Kanak-kanak. Jakarta: Rineka Cipta

Montolalu, dkk. (2009). Bermain dan Permainan Anak. Jakarta: Universitas Terbuka

Mulyati, dkk. (2011). Seni Menuangkan Gagasan. Jogyakarta: Kanisius

Munadi, Yudi. (2010). Media Pembelajaran: sebuah pendekatan baru. Jakarta: Gaung Persada

Nur Kasanah \& Tuminto. (2007). Kamus Bergambar. Jakarta

Sadiman, Arief S. (2007). Media Pendidikan: Pengertian, Pengembangan, dan Pemanfaatannya. Jakarta: RajaGrafindo Persada

Smaldino, Sharon E. (2011). Instructional Technology And Media For Learning: teknologi pembelajaran dan media untuk belajar. Jakarta: Kencana

Sujiono, Yuliani N, dkk. (2010). Bermain Kreatif Berbasis Kecerdasan Jamak. Jakarta: Indeks

Sugiyono. (2015). Metode Penelitian dan Pengembangan. Bandung: Alfabeta
Suyadi. (2010). Psikologi Belajar PAUD. Yogyakarta: Pedagogia

Undang-Undang Nomor 20 Tahun 2003 tentang Sistem Pendidikan Nasional 